http://journal.uin-alauddin.ac.id/index.php/lamaisyir

Publisher: Fakultas Ekonomi dan Bisnis Islam UIN Alauddin Makassar

\title{
Nazhir's Professionalism in the Management of Cash Waqf and Community Economic Empowerment
}

\section{Rachmat Effendi ${ }^{1}$, Ira Siti Rohmah Maulida ${ }^{2}$}

12Universitas Islam Bandung

muhammadrahmateffendi@gmail.com, irasitirohmahmaulida@gmail.com

Received: 24 Februari 2021; Revised: 22 Mach 2021; Published: 22 April 2021

\begin{abstract}
ABSTRAK
Penelitian ini mengkaji professionalisme Nadzir dalam mengelola wakaf uang dan memetakan kualitas kelembagaan wakaf dalam pengelolaan wakaf uang yang transparansi dan akuntabilitas dalam pertangungjawaban kepada stakeholder dan Allah Swt. Penelitian ini menggunakan metode kualitatif melalui observasi, wawancara, dan kajian dokumen. Hasil yang diperoleh menunjukkan bahwa beberapa Nadzir wakaf seperti, Yayasan Pesantren Islam Al-Azhar, Yayasan Dompet Dhu'afa, Yayasan Daaruttauhid, dan Yayasan Semai Sinergi Ummat (Wakaf Pro99), telah menunjukkan pengelolaan wakaf uang secara profesional, transparan dan akuntabel. Sistem pengelolaan keuangan menggunakan standar akuntansi zakat PSAK 109. Hasil audit akuntan publik independen menunjukkan opini Wajar Tanpa Pengecualian (WTP). Rata-rata 90\% hasil usaha digunakan kegiatan sosial dan pemberdayaan masyarakat melalui program Wakaf Integrated Farming (WIF), yang difokuskan pada bidang peternakan domba dengan sistem mudhorobah. Secara teoritis penelitian ini berkontribusi terhadap pengembangan keilmuan Manajemen Kelembagaan Islam pada Fakultas Dakwah, dan dapat dijadikan salah satu rujukan bagi Nadzir wakaf dalam pengelolaan wakaf uang dan aset wakaf pada umumnya.
\end{abstract}

Kata kunci: Professionalisme; Nadzir; Wakaf; Pemberdayaan.

\section{ABSTRACT}

This research examines Nadzir's professionalism in managing cash waqf, to map the quality of waqf institutions in the management of cash waqf in transparency and accountability in accountability to stakeholders and Allah SWT. This research uses qualitative methods through observation, interviews, and document review. The results obtained show that several Nadzir waqf, such as the Pesantren Islam Al-Azhar Foundation, the Dompet Dhafa Foundation, the Daaruttauhid Foundation, and the Semai Sinergi Ummat Foundation (Waqf Pro99), have demonstrated the management of cash waqf in a professional, transparent and accountable manner. The financial management system uses the zakat accounting standard PSAK 109. The results of an independent public accountant audit show an unqualified opinion (SWO). On average, 90\% of the business results are used by social activities and community empowerment through the Wakaf Integrated Farming (WIF) program, which is focused on the field of sheep farming using the mudhorobah system. Theoretically, this research contributes to the scientific development of Islamic Institutional Management at the Faculty of Da'wah, and can be used as a reference for Nadzir waqf in managing cash waqf and waqf assets in general.

Keywords: Professionalism; Nadzir; Wakaf; Empowerment 


\section{PENDAHULUAN}

Pada masa kepemimpinan Rasulullah Saw di Madinah, asset wakaf menjadi salah satu instrument keuangan yang sangat berpengaruh terhadap kesejahteraan ummat, mengurangi kemiskinan (Atan \& Johari, 2017), meningkatkan indeks pembangunan (Mohamad et al., 2014), memenuhi keperluan ummat (Azrai Azaimi Ambrose, Gulam Hassan, \& Hanafi, 2018), dan dapat meningkatkan perekonomian ummat (Shaikh, Ismail \& Mohd Shafiai, 2017), serta sosio-ekonomi (Ridwan, 2018). Bahkan pada zaman Bani Mamluk dan Turki Usmani Wakaf uang berkembang pesat (Effend, Rachmat: 2021).

Mengingat potensi wakaf sangat tinggi, maka akhir-akhir ini sering dijadikan tipo utama oleh para cendikiawan muslim, ulama, dan pakar ekonomi Islam dalam seminar dan diskusi, baik di tingkat nasional maupun internasional. Seperti di Turki, Syiria, Palestina, Iraq, Sudan, Maroko, Arab Saudi, Malaysia, termasuk di Indonesia (Effend, Rachmat: 2021). Demikian pula penelitian tentang Wakaf yang diarahkan pada pemberdayaan ekonomi ummat telah banyak dilakukan. Misalnya pendayagunaan wakaf untuk usaha mikro, kecil dan menengah (UMKM) di Malaysia melalui pendekatan takafful models (Mikail, Ahmad, \& Adekunle, 2017). Program Tabungan Wakaf Indonesia (TWI), melalui sektor properti oleh Dompet Dhu'afa Indonesia (Siswanto \& Suprapto, 2014). Pemberdayaan pendidikan (Mokhtar Ismail, Hairullfazli Muhammad Som, Mohd Isa Mohd Deni, \& Muna Sulaiman, 2015). Penanganan kesehatan di Masjid Agung Semarang (Usman, 2014). Pengelolaan Pengembangan Wakaf Uang Berdasarkan Peraturan Pemerintah No. 42 Tahun 2006 Pasal 48 Pada Bank BPD DIY Syariah (Setyadi, 2017), Professionalism of productive wakaf management assets in empowering the peoples economy in Indonesia And Malaysia Penelitian Kolaborasi Luar Negeri UNISBA Indonesia dengan USIM Malaysia (Setiadi dkk. 2020)

Lahirnya Undang-Undang Wakaf, No. 41 Tahun 2004, di Indonesia menjadi momentum bagi pemberdayaan Wakaf secara produktif, sebab di dalamnya terkandung pemahaman yang komperhensif dan pola manajemen pembayaran potensi Wakaf Uang secara modern. Peneliti berasumsi, jika Undang-Undang No. 41 Tahun 2004 ini dapat dilaksanakan secara professional dan proporsional, akan memiliki efek yang berlipat ganda (multiplier effect) tehadap pemberdayaan ekonomi umat (Abdurrohman Kasdi, 2018). Dapat diproyeksikan sebagai sarana rekayasa sosial (social engineering), melakukan perubahan pemikiran, sikap dan perilaku umat Islam dalam peningkatan kesejahteraan ummat. Namun, penelitian tentang professionalisme Nadzir dalam pengelolaan Wakaf uang yang dikaitkan dengan pemberdayaan ekonomi ummat, masih belum banyak 
dilakukan. Padahal wakaf uang sangat penting, karena lingkup sasaran wakaf uang (waqif) bisa menjadi sangat luas bisa dibuat dalam pecahan yang disesuaikan dengan segmen muslim yang dituju dan memiliki kesadaran tinggi. Misalnya dalam pecahan Rp. 10.000, Rp. 25.000,-, dan seterusnya sampai dengan jutaan rupiah (Mustafa E. Nasution dalam Muhammad: 2019:328).

Berdasarkan pengamatan sementara peneliti di lapangan, profesionalisme Nadzir (pengelola Wakaf) cenderung masih ada keterbatasan khususnya dalam hal: (1) Pemahaman terhadap aset Wakaf uang (Chamidah, 2008). (2) Kompetensi pengelolaan dan pemberdayaan asset Wakaf uang (Mutalib \& Maamor, 2016); (3) Professional dalam sosialisasi dan memberi pemahaman terhadap masyarakat tentang Wakaf uang (Chamidah, 2008). Asset Wakaf yang difahami masih terbatas pada tanah, madrasah, masjid dan sarana social lainnya yang dipandang belum menghasilkan surplus Wakaf (Nasrullah, 2017). Sehingga manfaatnya masih belum dapat dirasakan secara merata oleh masyarakat muslim (Primadhyta, 2016; Priyaman, 2013).

Fenomena inilah kemudian, mengisyaratkan pentingnya penelitian yang difokuskan pada: Pertama, profesionalisme Nadzir dalam mengelolaan wakaf uang; Kedua, Pengelolaan wakaf uang secara transparan dan akuntable; Ketiga, strategi pemanfaatan wakaf uang dalam pemberdayaan ekonomi umat.

\section{METODE PENELITIAN}

Jenis penelitian ini adalah studi lapangan, tujuannya ingin memetakan model pengelolaan wakaf uang yang dilakukan oleh lembaga wakaf (Nadzir), menganalisis implikasi manajemen wakaf terhadap kualitas laporan keuangan yang transfaran dan akuntebel, dan pengaruhnya terhadap pemberdayaan ekonomi ummat. Pendekatan yang digunakan adalah pendekatan kualitatif deskriptif (Moleong, 2009). Paradigma fenomenologi naturalistik yang menekankan pada hakikat realitas sosial dan mengkaji apa yang muncul dalam masyarakat, sehingga dapat menafsirkan dan menjelaskan makna yang terkandung dalam berbagai kegiatan Nadzir wakaf dalam pemberdayaan ekonomi umat. Teknik yang digunakannya adalah observasi, wawancara dan studi dokumen/keputakaan. Data kualitatif dianalisis melalui langkah-langkah: Pertama, penulis menerapkan analisis isi, dalam hal ini peneliti menganalisis data komunikasi atau fenomena (Muhajir, 1990) untuk membuat kesimpulan yang obyektif dan sistematis dengan mengidentifikasi karakteristik pesan atau data (Holsti, 1969). Kedua, peneliti menggunakan analisis sintesis, dengan menelaah 
secermat mungkin tesis yang mengembangkan upaya pemberdayaan ekonomi yang dilakukan Nadzir wakaf uang. Nadzir/Lembaga wakaf yang dijadikan subjek penelitian adalah 4 (empat) Nadzir yang sudah berbadan hukum dan memperoleh nomor pendaftaran di Badan Waqat Indonesia (BWI) serta melakukan pengelolaan wakaf uang di samping melakukan kegiatan zakat, infaq dan shodaqoh keempat Nadzir dimaksud adalah: (1) Yayasan Pendidikan AlAzhar, nomor pendaftaran: 3.3.00033, berlokasi di Jakarta Selatan; (2) Yayasan Dompet Dhuafa, nomor pendaftaran 3.3.00100 berlokasi di Jakarta; (3) Yayasan Semai Sinergi Ummat WAKAF PRO99, nomor pendaftaran 3.3.00056; (4) Yayasan Daarut Tauhid, nomor pendaftaran 3.3.00101,

\section{HASIL PENELITIAN DAN PEMBAHASAN}

\section{Profil Nadzir Wakaf Uang}

Secara prinsip, wakaf uang dan wakaf lainnya dipandang dari aspek fiqih tidak ada perbedaan. Sistem wakaf memiliki unsur-unsur: pewakaf (Waqif), pemegang amanah wakaf (Nadzir), benda wakaf (Mauquf), penerima manfaat wakaf (Mauquf alaih), dan ikrar wakaf (Akad wakaf). (Depag RI, 2007)

Nadzir menurut undang-undang Wakaf, adalah pihak yang menerima harta benda Wakaf dari Waqif untuk dikelola dan dikembangkan sesuai dengan peruntukannya. Nadzir Wakaf, bisa perseorang, organisasi atau badan hukum, dengan catatan memenuhi semua persyarat nadzir yang ada dalam undang-undang Wakaf. Nadzir mempunyai tugas melakukan pengadministrasian harta benda Wakaf, mengelola dan mengembangkan harta benda Wakaf sesuai dengan tujuan, fungsi, dan peruntukannya, mengawasi dan melindungi harta benda Wakaf. Kemudian melaporkan pelaksanaan tugas kepada Badan Wakaf Indonesia.

Nadzir Wakaf dalam bentuk lembaga atau organisasi berbadan hukum, secara umum lebih memungkinkan untuk diupayakan ke arah pemberdayaan Wakaf. Hal ini, disebabkan adanya fakta di mana mayoritas pengelola Wakaf yang notabene nadzir perseorangan bekerja paruh waktu (84\%) dan tidak mendapat imbalan, sehingga pengelolaan tidak focus dan kurang professional. Sedangkan pengelolaan Wakaf yang dilakukan oleh nadzir dengan cara yang profesional dimungkinkan dapat memberi peluang bagi pemberdayaan Wakaf lebih produktif, juga memberi peluang penerapan 
prinsip-prinsip manajemen modern (Abdurrahman Kasdi, 2015). Kerangka ini, nadzir harus berusaha menampilkan performa yang professional.

Nadzir wakaf uang menurut salah seorang Komisioner Badan Wakaf Indonesia (BWI) dan salah seorang Ketua MUI Pusat (Jeje Jaenuddin) adalah:

“........Ada perbedaan antara Nadzir wakaf uang dengan Nadzir wakaf non uang. Syarat nadzir dalam wakaf uang lebih ketat lagi, tidak bisa individual dan sembarangan. Jika nadzir wakaf selain uang bisa perorangan, yayasan, ataupun ormas. Nadzir wakaf uang harus lembaga wakaf formal berbadan hukum dan mempunyai keahlian serta reputasi yang baik dalam pengelolaan keuangan berdasar syariah. Karena itu nadzir wakaf uang seyogyanya mendapat rekomendasi dari Lembaga Keuangan Syariah yang mempunyai lisensi."

Secara keseluruhan, berdasarkan data yang diperoleh dari Badan Wakaf Indonesia, Nadhir Wakaf di Indonesia yang terdaftar dan memiliki nomor pendaftaran di BWI sekitar 201 Nadhir. Penelitian ini diangkat 4 (empat) Nadzir sebagai responden sesuai dengan aktifitas Nadzir yang mengelola wakaf uang dan melakukan peberdayaan ekonomi masyarakat.

Profil keempat Nadzir dimaksud secara singkat adalah:

\section{Yayasan Dompet Dhuafa}

Yayasan Dompet Dhuafa, didirikan pada tanggal 2 Juli 1993, dengan berbadan Hukum Yayasan, melalui Akta No. 41, Tanggal 14 September 1994, di hadapan Notaris H. Abu Yusuf, S.H., No. 163/A.YAY. HKM/1996 /PNJAKSEL Tujuan utamanya ingin mengembangkan etos kerja masyarakat melalui dana ZISWAF yang dikelola berdasarkan "syari'ah." Pada tanggal 16 Juni 2011, mendapat pengakuan dari Badan Wakaf Indonesia (BWI) sebagai Nadzir Wakaf uang, dengan Nomor Pendaftaran 3.3.00100 tanggal 10 Februari 2015. Dana sebagai sumber wakaf dihimpun oleh Tabungan Wakaf Indonesia (TWI).

\section{Yayasan Daarut Tauhid}

Lembaga wakaf Yayasan Daruttauhid terbentuk pada tahun 1999, bersatu dengan lembaga zakat dan infak (Ziswaf). Pada tahun 2009, dibentuk Pusat Pengembangan (Pusbang) Wakaf DT yang terpisah dari lembaga ZIS. Pada tahun 2014, Pusbang Wakaf berubah menjadi Wakaf DT yang difokuskan pada penghimpunan dan pengelolaan dana wakaf, serta pengembangan aset wakaf untuk mencapai visi dan misi yang telah dirumuskan. Pada tahun 2018, Wakaf DT diperbesar dengan adanya Kantor 
Perwakilan Wakaf Eco Pesantren, Kantor Perwakilan Wakaf DT Jakarta, dan Kantor Perwakilan Wakaf DT Batam. 3.3.00101

\section{Yayasan Pendidikan Al-Azhar}

Aktifitas pengelolaan Wakaf Al-Azhar berdasarkan: SK YPI Al-Azhar Nomor: 10/VIIKEP/YPIA-P/1431. 2010, Ditetapkan di: Jakarta, Pada Tanggal: 3 Sya'ban 1431 H/15 Juli 2010. Tertanda: H. Hariri Hady (Ketua Umum) dan H. Badruzzaman Busyairi (Sekretaris Umum). Beralamat di Komplek Masjid Agung Al-Azhar Jl. Sisingamangaraja No. 6, Selong, Kebayoran Baru, Jakarta Selatan Telp./Fax. 021-7234624. Terdafta pada Badan Wakaf Indonesia dengan nomor pendaftaran 3.3.00033,

\section{Yayasan Sinergi Fundation}

Pada 14 Oktober 2002, embrio Yayasan Semai Sinergi Umat didirikan oleh Miftah Faridl, yang sekaligus menjadi Ketua Dewan Pembina. Turut serta menandatangani akta Yayasan sebagai anggota Dewan Pembina, antara lain: H. Rachmat Badruddin (Pengusaha / Ketua Dewan Teh Indonesia), H. Achmad Noe' man dan H. Erie Sudewo (Social Enterpreneur / Pendiri Dompet Dhuafa Republika). Adapun pendirian Yayasan tersebut disaksikan langsung di depan Notaris Evy Hybridawati Wargahadibrata. Seiring perkembangan lembaga, yang berbanding lurus dengan kompleksitas problematika umat yang mengemuka, menuntut perubahan format kelembagaan, sebagai bentuk penyelerasan. Karenanya, dalam Rapat Resmi Dewan Pembina per tanggal 17 Februari 2011, Embrio Yayasan Semai Sinergi Umat berubah menjadi Yayasan Semai Sinergi Umat (Sinergi Foundation). Perubahan tersebut secara formil disahkan dalam Akta Notaris Nomor 24, tanggal 17 Februari 2011, yang dibuat oleh Notaris Evi Hibridawaty, diputuskan oleh Keputusan Menteri Hukum dan Hak Asasi Manusia Republik Indonesia Nomor: AHU - 5622.AH.01.05. Tahun 2011 tentang Perubahan Anggaran Dasar Yayasan Pasal 1 dan Pasal 5, yaitu Perubahan Nama menjadi Yayasan Semai Sinergi Umat atau Sinergi Foundation Sinergi Foundation dikukuhkan sebagai Nadzir Wakaf, sesuai SK BWI (Badan Wakaf Indonesia) Surat Tanda Bukti Pendaftaran Nadzir Nomor Pendaftaran: 3.3.00056, serta sebagai Lembaga Amil Zakat sesuai SK Menteri Agama DJ.III/564 Tahun 2016.

\section{Kualitas Pengelolaan Wakaf Uang}

Komisioner Badan Wakaf Indonesia mengatakan bahwa: "Nadzir wakaf uang harus lembaga wakaf formal berbadan hukum dan mempunyai 
keahlian dan reputasi yang baik dalam pengelolaan keuangan berdasar syariah." kata lain bahwa pengelolaan wakaf uang harus dilakukan secara professional. Parameter profesional adalah amanah yakni: (1) terdidik dan tinggi moralitasnya, (2) memiliki keterampilan yang unggul dan berdaya saing, (3) memiliki kemampuan dalam melakukan pembagian kerja, (4) dapat melaksanakan kewajiban serta memperoleh hak yang adil, dan (5) memiliki standar operasional kerja yang jelas dan terarah (Abdurrahman Kasdi, 2015). Karena uang wakaf itu wajib terjaga dan terpelihara keutuhan dan kelanggengannya, maka investasi wakaf uang itu harus sangat hati-hati dan ketat agar tidak terjadi kerugian pada jumlah nominal uang wakaf.

Sekurang-kurangnya ada tiga tahap dalam pengelolaan keuangan wakaf, yaitu: penghimpunan dana, pengumpulan dana, dan pemanfaatan dana. Berdasarkan data yang diperoleh di lapangan, dalam penghimpunan dana, hampir rata-rata setiap Nadzir wakaf melakukan edukasi wakaf kepada masyarakat melalui berbagai kegiatan, misalnya mengadakan kajian wakaf baik di Masjid-Masjid maupun di Majlis Taklim, dan memanfatkan media sosial. Yang paling menarik bagi waqif adalah penjelasan pemanfaatan dan pendayagunaan wakaf yang tepat sasaran, lebih-lebih di saat masyarakat Indonesia banyak yang terkena dampak pandemi covid-19. Memudahkan pengumpulannya para Nadzir berupaya menggunakan pasilitas transfer wakaf, jemput wakaf dan kantor layanan donasi wakaf.

Menurut keterangan dari Nadzir wakaf Sinergi Foundation, hasilnya sangat signifikan. Mereka menunjukkan hasil penghimpuan wakaf dalam tiga tahun terakhir mengalami kenaikan 103 \% dari tahun 2017 ke 20018 walaupun dalam tahun 2018 ke 2019 ada penurunan sebesar - 69\% tapi tetap menunjukkan bahwa kesadaran masyarakat terhadap kegiatan wakaf masih tinggi. Sebagimana ditunjukkan dalam tabel 2 berikut:

Tabel 2. Penerimaan Wakaf Uang

\begin{tabular}{lcl}
\hline Tahun & Nilai penghimpunan & Ket. \\
\hline 2017 & 2.834 .858 .058 & \\
\hline 2018 & 5.758 .101 .697 & \\
\hline 2019 & 1.732 .195 .053 & \\
\hline
\end{tabular}

Sumber: laporan keuangan Sinergi Foundation

Para Nadzir yang menjadi subjek penelitian ini melakukan pengelolaan wakaf uang secara professional, transparan dan akuntabel. Mereka semua 
melakukan pengelolaan keuangan wakaf dengan menggunakan standar akuntasi zakat yakni PSAK 109. Setiap tahun laporan keuangan diaudit oleh akuntan publik independen, hasilnya menunjukkan opini Wajar Tanpa Pengecualian (WTP). Demikian, dapat dikatakan bahwa proses pengelolaan keuangan dana wakaf dilakukan dengan baik dan benar.

\section{Pemanfaatan Wakaf Uang dalam Pemberdayaan Ekonomi Ummat}

Di lihat dari segi tujuan dan kontribusi yang dapat diberikan oleh Nadzir Waqf uang, maka keberadaan Waqf uang (di Indonesia) menjadi sangat krusial. Setidaknya ada beberapa hal yang mengakibatkan pentingnya pemberdayaan Waqf uang: Pertama, krisis ekonomi menyisakan banyak permasalahan, jumlah penduduk miskin meningkat, ketergantungan akan utang dan bantuan luar negeri. Kedua, kesenjangan yang tinggi antara penduduk kaya dan penduduk miskin. Ketiga, Indonesia memiliki jumlah penduduk Muslim terbesar, memiliki potensi Waqf yang signifikan untuk dikembangkan. Keempat, sejumlah bencana yang terjadi terutama adanya pandemi covid-19 berdampak pada pada perekonomian masyarakat (Effendi, Rachmat, 2021)

Pemanfaatn wakaf uang yang dilakukan oleh para Nadir yang diarahkan pada pemberdayaan ekonomi masyarakat antara lain sebagai berikut:

Yayasan Pendidikan Al-Azhar, salah satu program yang dilakukannya dinamai Wakaf khairi, antara lain meliputi: cash wakaf, dan wakaf produktif. Cash wakaf salah satu usahanya adalah wakaf tunai musytarak, yakni hasil dari kerjasama antara Nadzir dan perusahaan atau instansi. Hasil kemudian dikelola lagi menjadi wakaf produkti. Jenis usaha yang dilakukannya adalah pembelian lahan garam RAMSOL, memorial garden, kerjasama crowdfunding lembaga keuangan syariah dengan bank BNI Syariah, Muamalat, dan CIMB Niaga Syariah, membangun ruko, membangun vila, apartemen untuk disewakan, baik yang bersifat permanen maupun yang sementara atau terbatas waktu (wakaf alazhar, 2018).

Yayasan Dompet Dhuafa, mengelola Wakaf produktif mayoritas pada bidang kesehatan. Sedangkan dalam pengembangan ekonomi masyarakat dilakukan antara lain dengan cara pendirian agro-industri nanas di Subang Jawa Barat sejak tahun 2018.

Yayasan Daarut Tauhid, melakukan program wakaf sarana dakwah, wakaf sadar pendidikan, wakaf ekonomi produktif, wakaf media dakwah, dan wakaf sarana kesehatan. Wakaf ekonomi productif meliputi: (1) optimalisasi aset wakaf dengan membangun Gedung Serbaguna Aula Daarul Hajj dan Dome, 
Pertokoan Bazar Wakaf DT, Kios di Jalan Gegerkalong Girang Bandung, Lapangan Parkir, Cottage Daarur Jannah, Gedung MQ FM, Wakaf Produktif Lebah Madu Talegong, dan Lapangan Futsal Kadungora. (2) wakaf ketahanan pangan dengan mengoptimalkan aset wakaf berupa lahan pertanian lokal untuk membantu memenuhi kebutuhan ketersediaan pangan masyarakat, yang aman, merata, terjangkau, serta membantu pemberdayaan para petani yang lahannya kian tergerus industri dan properti. Para petani diberi pelatihan manajemen dan pengelolaan pertanian dengan teknologi ramah lingkungan disertai pembinaan ruhiyah. Pengelolaan program ketahanan pangan memanfaatkan teknologi pertanian ramah lingkungan. (wakafdt, 2020)

Yayasan Semai Sinergi Ummat WAKAF PRO99, memiliki tiga program wakaf uang yang digunakan untuk: Pertma, aktivitas bisnis, dimana hasil bisnis tersebut $90 \%$ digunakan untuk kegiatan social dan pemberdayaan masyarakat. Kemudian 10\% untuk operasional program. Misalnya dalam usaha Toko Fashion (Vamoosh dan Yesamalika), Kuliner (Rumah Makan Ampera, Hai Coffe, Cuangki Serayu dan Ayam Geprek Pangeran), Properti Perumahan, dan Herbal. Kedua, aktivitas social, pendidikan dan kesehatan. Misalna program Firdaus Memorial Park (pemakaman muslim). Ketiga, program pemberdayaan ekonomi masyarakat, yang dinamai program Wakaf Integrated Farming (WIF). Program ini dibuat dalam rangka mendorong kegiatan ekonomi masyarakat berbasis wakaf, yang telah berjalan sejak tahun 2019. Aktifitasnya difokuskan pada bidang peternakan domba mulai dari pembibitan, penggemukan dan pemasaran hewan. Program dilakukan dengan pola kerjasama bersama masyarakat dengan sistem bagi hasil (mudlorobah) (Surahman, 2020), Pengembangannya mengintegrasikan bidang peternakan dengan pertanian. Karena kedua kegiatan tersebut saling berhubungan dan saling membutuhkan. Misalnya limbah tani jadi pakan ternak dan limbah ternak jadi pupuk pertanian.

Deskripsi data hasil penelitian ini mengisyaratkan bahwa pengembangan waqf uang memiliki nilai ekonomis yang sangat strategis, karena memiliki keunggulan-keunggulan di antaranya: Pertama, waqf uang jumlahnya bisa bervariasi sehingga seseorang yang memiliki dana terbatas sudah bisa memulai memberikan dana waqf-nya tanpa harus menunggu menjadi orang kaya atau tuan tanah terlebih dahulu, dengan program waqf uang akan memudahkan si pemberi waqf atau waqif untuk melakukan waqfnya. Seperti digambarkan oleh Mustafa E. Nasution (dalam Muhammad, 
2019:328), setiap orang muslim bisa berwakaf dari mulai, Rp 10.000,-, Rp 25.000,- 50.000,- , Rp 100.000,-Rp 500.000,- Rp 1.000.000,- Rp 2.000.000 dan seterusnya. Jika jumlah umat Islam yang ber-waqf 26 juta saja, maka bisa dihimpun dana lebih dari 22 trilliun setiap tahunnya. Kedua, melalui Waqf uang, aset Waqf yang berupa tanah kosong bisa mulai dimanfaatkan dengan pembangunan gedung atau diolah untuk lahan pertanian. Ketiga, dana Waqf uang juga membantu sebagian lembaga pendidikan Islam yang cash flow-nya fluktuatif dalam menggaji sivitas akademikanya. Keempat, umat Islam dapat lebih mandiri dalam mengembangkan dunia pendidikan tanpa harus bergantung pada anggaran pendidikan Negara. Kelima, Waqf uang bisa memberdayakan usaha kecil yang masih dominan di negeri ini. Keenam, Waqf uang dapat membantu perkembangan bank-bank syariah, dan BPR Syariah. Di samping itu, keunggulan Waqf uang, selain bersifat abadi atau jangka panjang, juga dana termurah tidak akan terjerat oleh bunga.

Agar dapat berkembang dengan baik, maka harus dipilih lembaga/nadzir wakaf uang yang profesional, kredibel dan terdaftar serta memperoleh ijin yang sah dari kementerian agama dan Badan Wakaf Indonesia (Kasdi, A., 2014). Kemudian pewakaf (Waqif) membuat ikrar wakaf yang dituangkan dalam akta ikrar wakaf uang. Atas nama siapa yang berwakaf, kepada lembaga/Nadhir wakaf apa ia menunjuk nadzir wakaf, kemudian untuk siapa hasil dan keuntungan wakaf uang diperuntukkan. Karena uang wakaf wajib terjaga dan terpelihara keutuhan dan kelanggengannya, maka investasi wakaf uang itu harus sangat hati-hati dan ketat. Para pebisnis tentu harus sangat hati-hati jika menggunakan modal uang wakaf, karena tidak boleh ada kerugian pada jumlah nominal uang wakaf. (Huda \& Heykal, 2010).

\section{KESIMPULAN}

Berdasarkan temuan penelitian, profesionalisme para Nadzir cenderung effektif, professional, transparan dan akuntabel. Pelaporan keuangan menggunakan standard akuntansi zakat "PSAK 109". Setiap laporan keuangan tahunan diaudit oleh akuntan publik independen, hasilnya memperoleh opini wajar tanpa pengecualian (WTP) dan sesuai dengan Undang-undang perwakafan. Jenis usaha yang dilakukan oleh Nadzir antara lain Toko Busana, Kuliner, Properti Perumahan, Pabrik dan lain-lain. Sistem kerjasama yang digunakan adalah akad mudharabah, qardh, dan musyarokah. Adapun program pemberdayaan ekonomi masyarakat 
meliputi bentuk mempekerjakan masyarakat pada perusahaan yang dibangun oleh Nadzir; dan kerjasama mengoptimalkan wakaf lahan pertanian terpadu dengan mengintegrasikan bidang peternakan dan pertanian. Limbah tani jadi pakan ternak dan limbah ternak jadi pupuk pertanian.

Sebagai rekomendasi, syogyainya dapat diproyeksikan sebagai sarana rekayasa sosial (social engineering), perubahan pemikiran, sikap dan perilaku umat Islam dalam meningkatkan kesejahteraan ummat. Secara teoris penelitian ini dapat dijadikan bahan kajian Manajemen Kelembagaan Dakwah di Fakultas Dakwah; kajian Manajemen keuangan dan akuntansi di fakultas Ekonomi, pengembangan ekonomi syari'ah di Fakultas Syari'ah. Sedangkan secara praktis, dapat dijadikan salah satu rujukan kebijakan pemerintah. Dapat dijadikan salah satu rujukan oleh para Nadzir dalam pengembangan wakaf uang sehingga bisa menjangkau semua lapisan masyarakat.

\section{DAFTAR PUSTAKA}

Atan, N. A. B., \& Johari, F. B. (2017). A review on literature of Waqf for poverty alleviation between 2006-2016. Library Philosophy and Practice, 2017(1).

Azrai Azaimi Ambrose, A. H., Gulam Hassan, M. A., \& Hanafi, H. (2018). A proposed model for Waqf financing public goods and mixed public goods in Malaysia. International Journal of Islamic and Middle Eastern Finance and Management, 11(3), 395-415. https://doi.org/10.1108/IMEFM-01-20170001

Chamidah, U. (2008). Pengelolaan Asset Wakaf Tunai Pada Lembaga Keuangan Syariah (Studi Pengelolaan Wakaf Tunai Di Baitul Mal Hidayatullah Malang). Retrieved from

http:/ / etheses.uin-malang.ac.id/4261/1/04210042.pdf

Departemen Agama, 2007, Fikih Wakaf, Jakarta, Dirjen Wakaf.

Effendi, M. Rachmat. (2021) Development Of Cash wakaf benefits Synergi Foundation In The Economic Empwerment Of The Ummah, Penelitian Kolaborasi Luar Negeri UNISBA Indonesia dengan USIM Malaysia, Amwaluna: Jurnal Ekonomi dan Keuangan Syariah, Vol. ... No. ... Page ...Online ISSN: 2540-8402 | Print ISSN : 2540-8399 
Holsti, C. R. (1969). Content Analysis for The Social Science and Humanities, Canada: Departement of Political Science University of British Colombia.

Huda, N., \& Heykal, M. (2010). Lembaga Keuangan Islam Tinjauan Teoritis dan Praktis. Jakarta: Kencana.

Kasdi, Abdurrohman. (2018). Dinamika Pengelolaan Waqf Di Negara-Negara Muslim. Ziswaf: Jurnal Zakat Dan Waqf, 4(1), 73.

https://doi.org/10.21043/ziswaf.v4i1.3032

Kasdi, A., 2014. Peran Nadzir Dalam Pengembangan Wakaf. Jurnal Zakat dan Wakaf. Vol 1 (2), https://journal.iainkudus.ac.id/index.php/Ziswaf/article/view/1483

Kasdi, Abdurrahman. (2015). Peran Waqf Produktif Dalam Pengembangan Pendidikan. Jurnal Pendidikan Islam, 3(2), 433-452. https://doi.org/10.21043/quality.V3I2.1917

Mikail, S. A., Ahmad, M. A. J., \& Adekunle, S. S. (2017). Utilisation of zakāh and Waqf fund in micro-takāful models in Malaysia: an exploratory study. ISRA International Journal of Islamic Finance, 9(1), 100-105.

https:// doi.org/10.1108/IJIF-07-2017-010

Mokhtar Ismail, Hairullfazli Muhammad Som, Mohd Isa Mohd Deni, \& Muna Sulaiman. (2015). Model Operasi Wakaf Pendidikan di Malaysia. International Conference on Cash Waqf (ICCW), 2015(May), 215-228.

Muhajir, N. (1990).Metodologi Penelitian Kualitatif, Yogyakarta : Rakesaraseh.

Muhammad Iqmal Hisham et al. (2018) Waqf Management Practices: Case Study in a Malaysian Waqf Institution, World Journal of Social Sciences, 8 (3), 112.

Muhammad. (2019), Sistem Keuangan Islam (Prinsip Dan Operasionalnya Di Indonesia), Rajawali Press, Depok.

Mutalib, H. A., \& Maamor, S. (2016). Utilization of Waqf property: Analyzing an institutional Mutawalli challenges in management practices. International Journal of Economics and Financial Issues, 6(7Special Issue), 36-41.

Nasrullah, Y. G. (2017). Kesadaran Waqf Produktif Masih Minim Dinilai Karena Pola Pikir. Retrieved from Hidayatullah.com website: https://www. hidayatullah.com/berita/nasional/read/2017/10/26/126556/ kesadaran-Waqf-produktif-masih-minim-dinilai-karena-pola-pikir.html 
Primadhyta, S. (2016). Menkeu Usul Pembentukan Badan Pengelola Aset Waqf RI. Retrieved from CNN Indonesia website:

https://www.cnnindonesia.com/ekonomi/20160516131106-78131021/menkeu-usul-pembentukan-badan-pengelola-aset-Waqf-ri

Priyaman, L. (2013). Manajemen Aset Waqf. Retrieved from Badan Waqf Indonesia website:

https://bwi.or.id/index.php/ar/publikasi/artikel/1195-manajemenaset-Waqf.html

Ridwan, M. (2018). Waqf Dan Pembangunan Ekonomi. ZISWAF: Jurnal Zakat Dan Waqf, 4(1), 105. https:/ / doi.org/10.21043/ziswaf.v4i1.3034

Sadeq, A. M. (2002). Waqf, perpetual charity and poverty alleviation. International Journal of Social Economics, 29(1-2), 135-151.

https://doi.org/10.1108/03068290210413038

Setyadi, Hendro. (2017), Pengelolaan Pengembangan Wakaf Uang Berdasarkan Peraturan Pemerintah No. 42 Tahun 2006 Pasal 48 Pada Bank BPD DIY Syariah, Iqtishodia, Jurnal Ekonomi Syariah, Vol. 2, No. 1,

Setiadi, Edi, M.Rachmat Effendi, Asep Ramdan Hidayat. (2020), Professionalism of productive wakaf management assets in empowering the peoples economy in Indonesia And Malaysia, Penelitian Kolaborasi Luar Negeri UNISBA Indonesia dengan USIM Malaysia, LPPM Unisba.

Shaikh, S. A., Ismail, A. G., \& Mohd Shafiai, M. H. (2017). Application of Waqf for social and development finance. ISRA International Journal of Islamic Finance, 9(1), 5-14. https://doi.org/10.1108/IJIF-07-2017-002

Siregar, D. D. (2004). Manajemen Aset: Strategi Penataan Konsep Pembanguan

Sirajuddin, S. S. (2018). Pemberdayaan Tanah Wakaf Sebagai Potensi Ekonomi Umat Di Masjid Al-Markaz Al-Islami Makassar. Laa Maisyir: Jurnal Ekonomi Islam, 5(1).

Siswanto, I. E., \& Suprapto, E. (2014). Management Productive Waqf Optimalization (Case Study Tabung Waqf Indonesia). Seminar Waqf Iqlimi, Universitas Sains Malaysia, 374-395.

Surahman Maman, Nurrohman, (2020), Analysis Of Maqâshid Al-Syarî'ah On The Application Of The Collateral In The Mudhârabah Contract In Sharia Financial Institutions, 
Usman, N. (2014). Pengelolaan Waqf produktif untuk kesehatan. Muaddib, 04(02), $1-20$.

Yayasan dompet dhuafa. (2016; 2018). Laporan Tahunan 2018 Dompet Dhuafa Menjawab Pangilan Zaman. Jakarta.

Wakaf alazhar. (2018). wakaf AlAzhar. Retrieved from wakaf alazhar website: http://wakafalazhar.com/

Wakafdt. (2020). wakaf Terpadu Daarut tauhid. Retrieved from wakafdt website: https://www.wakafdt.org/program-wakaf/ 